Revue d'études américaines. American Studies Journal

\title{
Contemporary "Ethnic" Popular Music: A Challenge to American Modernity?
}

\section{Claude Chastagner}

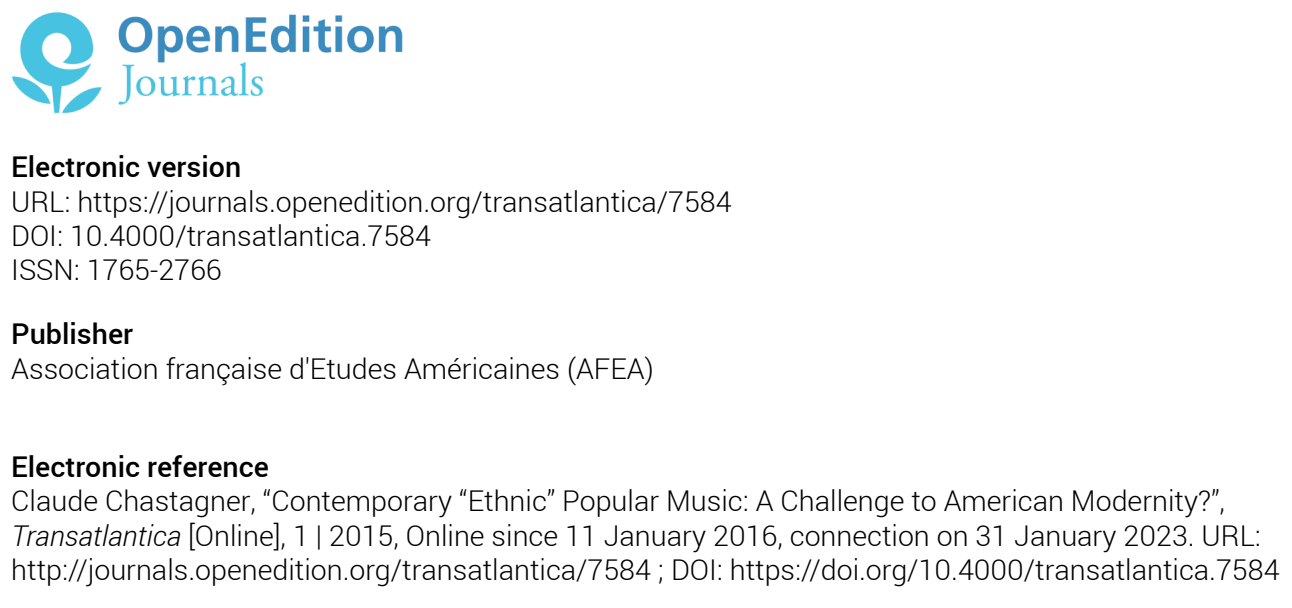

This text was automatically generated on 31 January 2023.

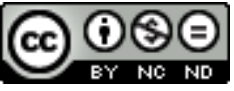

Creative Commons - Attribution-NonCommercial-NoDerivatives 4.0 International - CC BY-NC-ND 4.0

https://creativecommons.org/licenses/by-nc-nd/4.0/ 


\title{
Contemporary "Ethnic" Popular Music: A Challenge to American Modernity?
}

\author{
Claude Chastagner
}

1 Recently, a colleague in the Department of Chinese studies approached me regarding a Ph. D. dissertation on contemporary Chinese rock he had to read. The dissertation defined American rock music as the results of various processes of métissage and hybridization. This surprised him for he had always considered American popular music as a homogenized whole, the reflection of a global, hegemonic Anglo-Saxon culture, and the product of a consolidated, far-reaching industry. His reaction confirms the paradox of American culture identified by Denis Lacorne, i.e., a remarkably homogeneous image when seen from afar, but from the inside, a much more

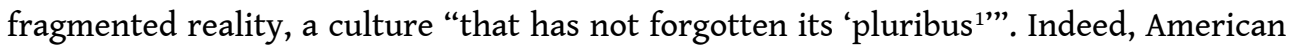
popular music, from jazz, or blues, to soul, rock, or country, boasts complex, culturally diverse roots, connected to specific historical and geographical contexts, and linked with distinct communities, defined by age, ethnic origins, social backgrounds, or gender. It belongs, along with most American popular art, to a multicultural environment stoked by the triple refusal of Anglo-Saxon hegemony, assimilation, and republican universalism, a perfect example of the "salad bowl" theory. However, as Denis Lacorne adds, one of the problems with the "salad bowl" theory is that there is no theory of the bowl itself ${ }^{2}$. Thus, if the various components of American popular music can fairly easily be traced and identified, how should we consider the final products and the industry that packages and markets them? How should we assess the hybridizing processes that give birth to the songs and dances? What about the economic, political, ideological superstructures that shapes them? In fine, to return to the initial question of my colleague, what is American popular music?

2 These issues are all the more relevant if we raise them not for the main bulk of American popular music, rock, blues, jazz, or country, i.e., the sounds that are not only commercially successful within the United States ${ }^{3}$, but represent American music 
abroad, but rather for other, less widespread genres, often dubbed "ethnic",", which have in recent years gained substantial interest, both within and outside the United States. They correspond to what Ani Difranco calls "the undercurrent of organically generated music 5 ", where by "organic" she probably means "not industrially produced", but rather crafted by a long lineage of artisan-musicians, working within specific traditions. Many of these styles have their origin outside the Anglo-American and African-American communities recognized today as the originators of the more popular genres mentioned above. They include chicken scratch, the music of the Tohono O'odham, and numerous other First American practices; Hawaiian slack-key guitar ; the decima of the Isleños, the immigrants from the Canary Islands living in the Mississippi delta ; bhangra, an off-shoot of the Indo-Pakistani diaspora, whose roots are both in India and Great-Britain ; Cajun and zydeco, in Francophone Louisiana, resulting from various waves of migrations, including the victims of the 1755 "Grand Dérangement", and those of the 1791 Haitian revolution; the various sounds of the Chicano communities, from conjunto to norteña, banda, or narcocorridos; salsa, rooted in the Cuban, Puerto-Rican, and Dominican immigration; klezmer, originally from Jewish circles; the polkas and tamburitzas of the Scandinavian and Central/Eastern European communities of the upper Midwest; or the sounds of the various East, and Southeast Asian groups, from Korean rap to Chinese jazz.

3 The music of the first comers of each new wave of immigration was mostly a faithful rendition of what they had heard or played at home. As nostalgic markers of an idealized homeland, the early recordings of these musical traditions met with unexpected success. Between 1908 and 1923, Pekka Gronow tells us, "Columbia issued about 6000 'foreign' records in the 'E' ('European') series. These were advertised regularly in the immigrant press and distributed through music stores in the ethnic neighborhoods". Ethnic programs on local radio stations enjoyed similar success. Among the countries represented in the catalogs or on the programs, one finds Finland, Ukraine, Sicily, Poland, Germany, Cape Verde, Greece, Albania, Portugal, Trinidad, Croatia, Norway, Puerto Rico, Austria, Turkey, Hungary, Switzerland, Romania, Spain, but also Syria, Thailand, Bali, India, China, Vietnam, Java, Laos, Burma, and Korea.

4 Soon however, immigrant audiences preferred sounds developed locally and more relevant to their new environment, rather than the original styles or performers. Accordingly, the ethnic musics that could not easily adapt and evolve to the burgeoning local taste disappeared. On the other hand, the music of the larger groups, particularly those living in tight-knit rural or urban communities, not only survived, but thrived. Such was the case after World War 2, for instance, of the Americanized "polka music" of the Slavic and Germanic populations. "Like a gigantic recycling machine, adds Gronow, America produced new creations and variations again and again. Songs were redone and reshaped, new lyrics, different instruments and rhythms were added, and tunes were altered slightly. Everybody borrowed from everybody else ${ }^{7 "}$.

5 These genres have resorted to different musical strategies, some with resounding commercial and critical success. Bhangra, for instance, or the latest forms of banda and narcocorridos, rely heavily on technology, and make frequent use of synthesizers, samplers, and remix techniques. Others have chosen on the contrary to focus on a more traditional instrumentation and repertoire: thus, the accordion, the clarinet, and the violin are staple features in conjunto, norteña, polka, Cajun, zydeco, or klezmer music, while the mele and the pahu drum are featured in Hawaiian music, and the pipa and the 
qeej in Chinese or Hmong styles (and even technologically savvy bhangra still relies on the traditional dhol drums and the tumbi). Hybridizing processes, involving different communities, are also the rule. Bhangra, salsa, klezmer and zydeco have established deep connections with African-American genres, including rap, techno, jazz, or reggae, while Cajun is closer to country music, or even Irish idioms. Tamburitza has cultivated its links with Croatia, and conjunto with its German and Czech origins. The list and its nuances would be endless.

6 Similarly heterogeneous practices can be observed in the marketing and economic development of non-Anglo music. If Laotian music develops mainly within the Laotian community, with few festivals or concerts directed towards outsiders, and scant media attention, on the contrary, klezmer has branched outside the Jewish community, with bands like The Klezmatics playing klezmer renditions of Woody Guthry to crossover success. In many regions, from the Midwest to Southwestern Louisiana, local councils have understood the economic interest of marketing these musics as tourist attractions, and in places like Lafayette, Louisiana, zydeco and Cajun have been turned into the engines of local development, with the risks of folklorization, dilution, and distortion inherent to performative, cultural marketing.

7 Academics have elevated many of these genres to the status of identity markers, connected to diasporic issues, and often along postcolonial or postmodern perspectives. Adelaida Reyes, for example, claims that "identity is the core issue of [American music]". She devotes one of the five chapters of her book to "Identity and American Music", using the example of the clave to show how music can be turned into an ethnic marker, here of Latino identity. Reyes carefully stresses how much the notions of "identity" or "community" are tricky. However, as François Laplantine suggests, the concept of "identity" is often used without such precautions as a performative statement disguised in constative one, creating, as much as describing, identities, for ideological, political, or economic purposes'. Identity, a concept whose primary meaning applies to the unique character of an individual, is thus given a collective dimension, as if the community possessed essences and characteristics shared by all its members. Though difference is an essential component of one's identity (the dynamics of multiculturalism, for instance, is as much about how different one feels from the rest of society, as about the extent to which one identifies with other individuals sharing similar characteristics or values), most analyses of ethnic musics insist rather on the "belonging" dimension, on how these musics "work" for the communities.

8 The ambiguity of the concept of identity, referring both to similarity and difference, common elements and specificities, could thus be harnessed to erroneously stress the collective at the expenses of the individual. Transforming a musical genre into an explicit and self-conscious "identity marker", related to a group of individuals who constitute a "community" only in the eyes of sociologists or anthropologists, runs the risk of approaching these communities as coherent wholes, determined by "permanent and immutable cultural characteristics ${ }^{10}$ " and thus of denying the individual members of these communities the possibility (or even the capacity) of historicism and change. The Mexican-Americans musicians living (and very often born) in the Upper Midwest are a telling example of the limits of too systematically equating a specific culture and environment with a given music. Pedro Rangel, of the band La Otra Midad explains how he plays indifferently Serbian, Scandinavian, Croatian, German, or Jewish music, while 
his band includes Irish, Mexican, and Italian players: "Anybody who requests any kind of number, no matter what country it is, we'll play any type of ethnic music [...] We're losing some culture to other cultures, making one pure culture impure, but it's good ${ }^{11}$ ".

A feature common to most non-Anglo music genres was for long their stigmatization as the music of unsavory, thick, despicable immigrants, the music of spics, greasers, kikes, krauts, gooks, dinks, coonasses, mahouts, or chinks. Accordingly, their music was disparaged as unpleasant and stupid, creating a sense of shame and humiliation in many non-Anglo youth, and prompting them to forsake the music connected to their origins. Anglo Indian musician Bally Sagoo recalls: "Before, you were embarrassed to blast an Asian tune in your car 'cos the people were looking [...] You know, I had to wind up the windows when I was blasting an Indian track a few years ago because it was, 'What's this sound?12'" Chicano kids experienced similar feelings. For years, Michael Ramos, the founder and leader of Charanga Cakewalk, was ashamed of his Mexican heritage: "Growing up, I was trying to not stand out and draw attention to myself. I tried to keep the Mexican music away from my friends that weren't Mexicans, as it was a very embarrassing thing for me. If we were in the car, I would turn the music down or off. The accordion being the lead instrument in conjunto and Latin music at the time, I was even more ashamed of it. I tried to stay away form accordion music as much as possible. ${ }^{13 "}$ The same is true in most communities. The Cajun fiddler D. L. Menard recalls "Mama, they used to laugh at us at school ${ }^{14}$ ", an experience shared by Geno Delafosse, a zydeco accordion player: "When I first got started playing with Daddy, French music and zydeco and all that stuff wasn't cool. Young people didn't listen to it [...] a lot of my classmates, they would laugh at $\mathrm{me}^{15 "}$.

10 Things have changed, or at least are changing. Much of the music originating from nonAnglo communities is now sought after by the very people who mocked, or ignored it. It is often heard in clubs, on major national television or radio programs. Its performers have received accolades from the mainstream press, have been asked to collaborate with leading musicians in various established genres, pop, rock, hip hop, etc., from Missy Elliot to Paul Simon, Jay-Z to the Kronos Quartet. The National Heritage Fellowship program created in 1983 by the National Endowment for the Arts to honor traditional artists systematically includes non-Anglo musicians. In 2013, for instance, the list featured Nicolae Feraru (Romanian-American), Carol Fran (French Creole) and Ramón "Chunky" Sánchez (Mexican-American).

11 "Ethnic" artists have become the epitome of cool, they point to an exciting, global modernity and their recognition suggests that they are now included, as well as the communities they come from, in the American dynamic of "progress". However, despite the currency of these genres, and their reliance on contemporary musical and marketing techniques, they also get talked about by much of the media, and enjoyed by a large fraction of their newly-found audience as traditional forms, a connection to disappearing roots, to a distant past perceived as slower and simpler, and thus better, to an exotic, enticing "ailleurs", an elsewhere whose remoteness is both spatial and temporal ${ }^{16}$.

12 So that the issue these genres eventually raise is that of the "modern". To what extent are these musics modern? Do they flag the communities that produce them as excitingly contemporary? Or do they on the contrary point to their quaint and traditional dimensions that the pace of fads and fashions and the uneasiness triggered 
by an increasingly globalized world have turned into highly valued qualities? And more fundamentally, what conception of modernity do they refer to?

Such issues can be best approached through the framework of Sareee Makdisi's analysis of modernity. He posits that the way the West conceptualized modernity (and later, postmodernity) was as a promise more than a fact, a future rather than a present, something "always already displaced and deferred", "the promise of what turns out to be a perpetually deferred future happiness ${ }^{17 "}$. This is the perspective the Nahda movement, for instance, adopted in the late $19^{\text {th }}$ century to advocate for a modernization of the Arab world. It included a conception of development restricted to the scale of self contained, autonomous, independent States and national economies, a conception which ran against the more traditionalist, pan-Arab approach advocated by various, often religious, groups, calling for "the reinvention of some vanished moment of past glory ${ }^{18 "}$. Modernity was thus construed either as the future or as the past.

Makdisi uses instead the focus on the present developed by a number of outstanding literary works to elaborate an alternative to these two antagonistic, and according to him, equally misguided conceptions, and to define a "third way" modernity as "an uncompromising and inescapable [...] highly unstable and contradictory present, one that defies the convenient and false reassurances of new and old political, religious, and literary dogmatisms ${ }^{19}$ ". Such a conception of modernity, different from both Eurocentric dreams of the future and Islamic traditionalism, insists on the necessity to confront, here and now, the problems of relegated individuals or communities, rather than fruitlessly evoke utopian, future or past solutions. In the United States too, the social, economic, and political present of many individuals belonging to depressed or derided immigrant communities has to be addressed. Praising alternatively the "modernity" or the "traditionalism" of these musics, turning them into the latest "cool" embraced by postmodernist hipsters, or a nostalgic escape adopted by disoriented citizens could be a strategy, albeit unconscious, to ignore the contemporary realities of these communities.

Additionally, to the same extent as the "third way" modernism Makdisi advocates can be apprehended as a form of opposition to First World's conceptions of modernity (including, of course, its economic, capitalistic organization) ${ }^{20}$, the musics dealt with in this issue represent a reassessment and contestation of the concept of late capitalist logic defended by the United States and other First World countries. As the study of contemporary ethnic music reveals, transnational flows as well as the development of smaller, trans-border, regional units undermine and outmode the twin logic of the Nation-State and capitalism for both symbolic and pragmatic reasons ${ }^{21}$. Rather than the utopian postmodernity or the nostalgic past they are said to embody, these musics suggest that modernity can be apprehended as a contemporary and immanent condition. They underscore complex, most often problematic intra- and inter-groups exchanges and flows, or hybridization processes that involve the present lives of individuals, and have to be dealt with in the present.

Reyes reminds us that "Musics have been labeled as though they were single, culturally indivisible units. [...] music, like the nation-state and its language, have been presumed governed by a single system ${ }^{22 "}$. Hence the reaction of my colleague I alluded to in the first lines of this introduction, for whom American music was a single, unified whole. But these assumptions are now challenged and such may be the ultimate questioning triggered by the analysis of ethnic musics in the United States. Does not their inherent 
transnational quality, often purposefully emphasized ${ }^{23}$, preclude from calling them American? Can we still consider them as American music? Or rather, what about them is American? Is not the very term "American", and the American Nation-State it refers to, an obsolete and irrelevant structure, the frame of the "Nation" (the cultural realm) no longer coinciding with that of the "State" (the political frame)? Accordingly, "The Music Box" section of Transatlantica has chosen to study, in two separate installments, a number of ethnic musics in the light of the most recent technological, structural, and economic developments, and explore them in connection with the issues mentioned above. Our purpose is to try and answer some of the more specific following questions: How has the music industry fostered or adapted to these developments? What is the impact of the new on-line media on the dissemination and consumption of ethnic music? Have live performances acquired a different role and importance? What are the new business models connected to the ubiquitous use of the Internet and new forms of financing (crowd funding, $360^{\circ}$ deals)? Are paradigms of "cultural identity" (integration, assimilation, etc.) still relevant to describe how cultural practices are having an impact on ethnic and social groups?

This first installment focuses on three specific musical practices originating outside Anglo communities. Helena Simonett and César Jesús Burgos Dávila study Mexican pointy-boots and "tribal music", an extension of Chicano music that has attracted a lot of attention. Marie Demars traces how contemporary zydeco groups use Facebook and Twitter to expand their fan base. Anjali Gera Roy deals with the sudden expansion in the urban context of New York of originally rural forms of bhangra

In the next issue of Tansatlantica, Frédéric Döhl will explore the use of the Internet and YouTube in recent developments of the Barbershop "tradition". Richard March will also analyse the consequences of new digital media on the nature of the interaction between polka enthusiasts, and Barry J. Ancelet will comment on the impact of festival playing and mainstream recognition on the way Cajun music is now being performed.

\section{BIBLIOGRAPHY}

CHEMILLIER-GENDREAU, Monique, De la guerre à la communauté universelle, Entre droit et politique, Paris, Fayard, 2013.

DELIÈGE, Robert, Contre (la) culture, Unpublished, 2014.

DI FRANCO, Ani, "Preface." In River of Song, A Musical Journey Down the Mississippi, Wald, Elijah and John Junkerman, New-York, St Martin's Press, 1999.

GREENE, Victor, A Passion for Polka: Old-Time Ethnic Music in America, Berkeley, University of California Press, 1992.

GRONOW, Pekka, “The Early Ethnic Record Industry in the US”, Liner notes, Stranded in America, Early Songs of Emigration. Trikont, 2005. 
LACORNE, Denis, La Crise de l'identité américaine. Du melting pot au multiculturalisme, Paris, Fayard, 1997.

LAPLANTINE, François, Je, nous et les autres : êtres humains au-delà des appartenances, Paris, Le Pommier, 1999.

MAKDISI, Saree, “'Postcolonial' Literature in a Neocolonial World: Modern Arabic Culture and the End of Modernity", Boundary 2, vol. 22, N 1 (Duke University Press, Spring, 1995), pp. 85-115. REYES, Adelaida, Music in America. Experiencing Music, Expressing Culture, New York, Oxford University Press, 2005.

SHARMA, Sanjay, "Re-mixing Identities: Off the Turn-Table”, In Dis-Orienting Rhythms: The Politics of the New Asian Dance Music, Sanjay Sharma et al., eds., London, Zed, 1996 ; 81-104.

WAGNER, Christophe, "In the catacombs of old America, from the music of the immigrants to rock 'n' roll”, Liner notes, Stranded in America, Early Songs of Emigration, Trikont, 2005.

FURTHER READING

General

COHEN, Norm, ed., Ethnic and Border Music: A Regional Exploration, Westport, Greenwood Press, 2007.

LORNELL, Kip, The NPR Curious Listener's Guide to American Folk, New York, Grand Central Press, 2004.

LORNELL, Kip \& Anne K. RASMUSSEN, eds., Musics of Multicultural America: A Study of Twelve Musical Communities, New York, Schirmer Books, 1997.

MALONE, Bill C. and David STRICKLIN, Southern Music/American Music, Lexington, The University Press of Kentucky, 2003.

SIMONETT, Helena, ed., The Accordion in the Americas. Klezmer, Polka, Tango, Zydeco, and More !, Urbana, University of Illinois Press, 2012.

SPOTTSWOOD, Richard K., Ethnic Music on Records. A Discography of Ethnic Recordings Produced in the United States, 1893 to 1942, 7 vols., Urbana, University of Illinois Press, 1990.

STOKES, Martin, ed., Ethnicity, Identity and Music, Providence, Berg, 1994.

TAYLOR, Timothy D., Global Pop: World Music, World Markets, New York, Routledge, 1997.

TURINO, Thomas and James LEA, eds., Identity and the Arts in Diaspora Communities, Detroit, Harmonie Park Press, 2004.

WALD, Elijah \& John JUNKERMAN, River of Song, A Musical Journey Down the Mississippi, New York, St Martin's Press, 1999.

Cajun and Zydeco

ANCELET, Barry J., “Zydeco/Zarico: Beans, Blues and Beyond”, Black Music Research Journal, vol. $8, \mathrm{n}^{\circ} 1,1988$, p. 33-49.

-, \& Elemore MORGAN Jr., The Makers of Cajun Music: Musiciens cadiens et creoles, Austin, University of Texas Press, 1984.

BERNARD, Shane K., Swamp Pop: Cajun and Creole Rhythm and Blues, Jackson, University Press of Mississippi, 1996. 
BORDERS, Florence E., "Researching Creole and Cajun Musics in New Orleans", Black Music Research Journal, vol. 8, n 1, 1988, p. 15-31.

BROVEN, John, South to Louisiana: The Music of the Cajun Bayous, Gretna, Pelican, 1983.

LE MENESTREL, Sara, "French music, Cajun, Creole, Zydeco", Civilisations [Web], n 53, 2005, on line 24/1/2009, consulted 29/3/2012, http://civilisations.revues.org/index579.html.

-, Negotiating Difference in French Louisiana Music: Categories, Stereotypes, and Identifications, Jackson, University Press of Mississippi, 2015.

MINTON, John, "Houston Creoles \& Zydeco: the Emergence of an African American Urban Popular Style", American Music, vol. 14, n 4, 1996, p. 480-526.

SACRÉ, Robert, Musiques Cajun, Créole et Zydeco, Paris, Presses Universitaires de France, 1995.

SAVOY, Ann, Cajun Music, a Reflection of a People, Eunice, Bluebird Press, 1984.

TISSERAND, Michael, The Kingdom of Zydeco, New York, Arcade, 1998.

WOOD, Roger \& James FRAHER, Texas Zydeco, Austin, University of Texas Press, 2006.

Chicano music

COHEN, Norm, ed., Ethnic and Border Music: A Regional Exploration, Westport, Greenwood Press, 2007.

EDBERG, Mark Cameron, El Narcotraficante: Narcocorridos and the Construction of a Cultural Persona on the U.S.-Mexican Border, Austin, University of Texas Press, 2004.

LORNELL, Kip and Anne K. RASMUSSEN, eds., Musics of Multicultural America: A Study of Twelve Musical Communities, New York, Schirmer Books, 1997.

LOZA, Steven, Barrio Rhythm: Mexican American Music in Los Angeles, Urbana and Chicago, University of Illinois Press, 1993.

MADRID, Alejandro L., Nor-tec Rifa! Electronic Dance Music from Tijuana to the World, New York, Oxford University Press, 2008.

-, Transnational Encounters: Music and Performance at the U.S.-Mexico Border, New York: Oxford University Press, 2011.

PAREDES, Américo, "With His Pistol in His Hand": A Border Ballad and Its Hero, Austin, University of Texas Press, 1958.

-, A Texas-Mexican Cancionero: Folksongs of the Lower Border, Austin, University of Texas Press, 1995.

PEÑA, Manuel, The Texas-Mexican Conjunto: History of a Working-Class Music, Austin, University of Texas, 1985.

-, The Mexican American Orchestra: Music, Culture, and the Dialectic of Conflict, Austin, University of Texas Press, 1999.

-, Música Tejana: The Cultural Economy of Artistic Transformation, College Station, Texas A \& M University Press, 1999.

RAGLAND, Catherine, Música Norteña: Mexican Migrants Creating a Nation between Nations, Philadelphia, Temple University Press, 2009.

REYES, David, and Tom WALDMAN, Land of a Thousand Dances: Chicano Rock 'n' Roll from Southern California, Albuquerque, University of New Mexico Press, 2009. 
SAN MIGUEL Jr., Guadalupe, Tejano Proud: Tex-Mex Music in the Twentieth Century, College Station, Texas A \& M University Press, 2002.

SHEEHY, Daniel, Mariachi Music in America: Experiencing Music, Expressing Culture, Oxford, Oxford University Press, 2005.

SIMONETT, Helena, Banda: Mexican Musical Life Across Borders, Hanover \& London, Wesleyan University Press, 2001.

TEJEDA, Juan and Avelardo VALDÉZ, eds., Puro Conjunto: An Album in Words and Pictures, Austin, University Press of Texas, 2001.

WALD, Elijah, Narcocorrido. A Journey Into the Music of Drugs, Guns, and Guerillas, New York, Rayo, 2001.

Bhangra

DIETHRICH, Gregory, "Desi Music Vibes: The Performance of Indian Youth Culture in Chicago", Asian Music vol. 31, No. 1 (Autumn 1999 - Winter 2000): 35-61.

-, "Dancing the Diaspora: Indian Desi Music in Chicago", Identity and the Arts in Diaspora Communities, Thomas Turino and James Lea, eds., Detroit, Harmonie Park Press, 2004, 104-115. ROY, Anjali Gera, Bhangra Moves: From Ludhiana to London and Beyond, Aldersgate, Ashgate 2010.

SANJAY, Sharma et al, eds., Dis-Orienting Rhythms: The Politics of the New Asian Dance Music, London, Zed, 1996.

WARWICK, Jacqueline, "Can Anyone Dance to this Music? A Study of Toronto's Bhangra scene", Bansuri, vol. 12 (1995): 5-17.

Polka

DOLGAN, Bob, America's Polka King: the Real Story of Frankie Yankovic and his Music, Cleveland, Gray \& Company, 2006.

GREENE, Victor, A Passion for Polka: Old-Time Ethnic Music in America, Berkeley, University of California Press, 1992.

KEIL, Charles, Angeliki V. KEIL, and Dick BLAU, Polka Happiness, Philadelphia, Temple University Press, 1992.

LEARY, James P., Polkabilly: How the Goose Island Ramblers Redefined American Folk Music, New York, Oxford University Press, 2006.

MARCH, Richard, The Tamburitza Tradition, Madison, University of Wisconsin Press, 2013.

\section{NOTES}

1. Denis Lacorne, La Crise de l'identité américaine. Du melting pot au multiculturalisme, Paris, Fayard, 1997, 386.

2. Lacorne, op. cit., 387.

3. However, these questions are seldom asked about "art" music (classical, or avant-garde), though it has been the site of similar hybridizing processes since its earliest developments.

4. See for instance Christophe Wagner, "In the catacombs of old America, from the music of the immigrants to rock 'n' roll", liner notes to Stranded in America, Early Songs of Emigration, Trikont, 2005. We have chosen to keep the term "ethnic", despite its limitations, to refer to 
musical styles that do not have their main roots in the combination of Anglo-Irish, and African traditions.

5. Ani Difranco, "Preface", in River of Song, A Musical Journey Down the Mississippi, Wald, Elijah and John Junkerman, New York, St Martin's Press, 1999, 9.

6. Pekka Gronow, "The Early Ethnic Record Industry in the US", liner notes to Stranded in America, Early Songs of Emigration, Trikont, 2005.

7. Gronow, op. cit.

8. Adelaida Reyes, Music in America. Experiencing Music, Expressing Culture, New York, Oxford University Press, 2005, xii.

9. François Laplantine, Je, nous et les autres : êtres humains au-delà des appartenances, Paris, Le Pommier, 1999, 19.

10. Robert Deliège, Contre (la) culture (Unpublished, 2014), 103.

11. Elijah Wald \& John Junkerman, River of Song, A Musical Journey Down the Mississippi, New York, St Martin's Press, 1999, 95.

12. Sanjay Sharma, "Re-mixing Identities: Off the Turn-Table", Dis-Orienting Rhythms: The Politics of the New Asian Dance Music, Sanjay Sharma et al., eds., London, Zed, 1996, 91.

13. Personal interview, Austin, TX, November 2012.

14. Wald, op.cit., 277.

15. Wald, op. cit., 283.

16. See for example Victor Greene, A Passion for Polka: Old-Time Ethnic Music in America, Berkeley, University of California Press, 1992.

17. Saree Makdisi, “'Postcolonial' Literature in a Neocolonial World: Modern Arabic Culture and the End of Modernity”, Boundary 2, vol. 22, N 1, Spring, 1995, p. 90, 96, 98.

18. Makdisi, op. cit., 99.

19. Makdisi, op. cit., 99.

20. Makdisi, op. cit., 112.

21. Leading contemporary thinkers have established the extent to which political organizations based on the Nation-State and capitalism rely on each other, and have advocated alternative political structures (see for instance Chemillier-Gendreau).

22. Reyes, op. cit., 11.

23. See for instance the Nor-tec movement, based in Tijuana, which has attracted audiences from the United States and Western Europe, as described by Alejandro L. Madrid in Nor-tec Rifa! Electronic Dance Music from Tijuana to the World, New York, Oxford University Press, 2008.

\section{AUTHOR}

\section{CLAUDE CHASTAGNER}

Université Paul-Valéry, Montpellier 3 